\title{
Probing Defects in Nitrogen-Doped
}<smiles>[14CH3]O</smiles>

SUBJECT AREAS:

MATERIALS FOR ENERGY AND CATALYSIS

CHEMICAL PHYSICS

Received

1 August 2014

Accepted

7 November 2014

Published

28 November 2014

Correspondence and requests for materials should be addressed to Z.M. (zxmei@iphy.ac. cn) or X.D. (xldu@iphy. ac.cn)
Junqiang Li' , Zengxia Mei', Lishu Liu', Huili Liang' , Alexander Azarov² , Andrej Kuznetsov², Yaoping Liu', Ailing $\mathrm{Ji}^{3}$, Qingbo Meng' \& Xiaolong $\mathrm{Du}^{1}$

'Key Laboratory for Renewable Energy, National Laboratory for Condensed Matter Physics, Institute of Physics, Chinese Academy of Sciences, P.O. Box 603, Beijing 100190, China, ${ }^{2}$ Department of Physics, University of Oslo, P.O. Box 1048 Blindern, NO-0316 Oslo, Norway, ${ }^{3}$ State Key Laboratory for Surface Physics, National Laboratory for Condensed Matter Physics, Institute of Physics, Chinese Academy of Sciences, P.O. Box 603, Beijing 100190, China.

Nitrogen doping is a promising method of engineering the electronic structure of a metal oxide to modify its optical and electrical properties; however, the doping effect strongly depends on the types of defects introduced. Herein, we report a comparative study of nitrogen-doping-induced defects in $\mathrm{Cu}_{2} \mathrm{O}$. Even in the lightly doped samples, a considerable number of nitrogen interstitials $\left(\mathrm{N}_{\mathrm{i}}\right)$ formed, accompanied by nitrogen substitutions $\left(\mathrm{N}_{\mathrm{O}}\right)$ and oxygen vacancies $\left(\mathrm{V}_{\mathrm{O}}\right)$. In the course of high-temperature annealing, these $\mathrm{N}_{\mathrm{i}}$ atoms interacted with $\mathrm{V}_{\mathrm{O}}$, resulting in an increase in $\mathrm{N}_{\mathrm{O}}$ and decreases in $\mathrm{N}_{\mathrm{i}}$ and $\mathrm{V}_{\mathrm{O}}$. The properties of the annealed sample were significantly modified as a result. Our results suggest that $\mathrm{N}_{\mathrm{i}}$ is a significant defect type in nitrogen-doped $\mathrm{Cu}_{2} \mathrm{O}$.

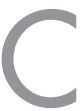

uprous oxide $\left(\mathrm{Cu}_{2} \mathrm{O}\right)$, a p-type semiconductor with a direct band gap of $2.1 \mathrm{eV}$, has long been considered a promising material for low-cost solar-energy conversion and photocatalysis ${ }^{1-5}$. Its advantages include a high absorption coefficient, a suitable band-gap width, chemical stability, non-toxicity and abundant reserves. Nitrogen doping in $\mathrm{Cu}_{2} \mathrm{O}$ is an important research topic because of its tremendous potential for overcoming the major disadvantage of $\mathrm{Cu}_{2} \mathrm{O}$ - its high resistance. Moreover, recent research has revealed that in addition to conductivity improvement, nitrogen-doped $\mathrm{Cu}_{2} \mathrm{O}$, hereafter referred to as $\mathrm{Cu}_{2} \mathrm{O}: \mathrm{N}$, exhibits enhanced light absorption below the band gap, most likely because of the introduction of an intermediate band (IB) located $\sim 0.7 \mathrm{eV}$ above the valence band maximum $(\mathrm{VBM})^{6,7}$. Its advantageous band gap and IB level have made $\mathrm{Cu}_{2} \mathrm{O}: \mathrm{N}$ an excellent candidate material for IB solar cells 8 . Its enhanced subband absorption in combination with its excellent visible-light absorption is also an outstanding advantage for photocatalysis because most inorganic photocatalysts suffer from poor activity or even inactivity under visible-light illumination, including the extensively studied $\mathrm{TiO}_{2}$ and perovskite compounds ${ }^{9-11}$. However, several other groups have observed no enhancement in subband absorption even in heavily doped $\mathrm{Cu}_{2} \mathrm{O}: \mathrm{N}$ films ${ }^{12,13}$, and Nakano et al. even observed a band-gap-widening effect upon nitrogen doping ${ }^{14}$.

Through the application of first-principles calculations, several theoretical investigations of $\mathrm{Cu}_{2} \mathrm{O}: \mathrm{N}$ have also been performed. $\mathrm{Li}$ et al. claimed that nitrogen impurities in $\mathrm{Cu}_{2} \mathrm{O}$ induce a marked widening of the band gap when oxygen vacancies are present ${ }^{15}$, which could account for the experimentally observed optical band-gap widening of $\mathrm{Cu}_{2} \mathrm{O}: \mathrm{N}$ prepared via the sputtering technique ${ }^{14}$. Conversely, Zhao et al. reported a theoretical prediction that nitrogen doping should slightly widen the band gap, causing the formation of an IB in the gap located at $\sim 0.9 \mathrm{eV}$ above the $\mathrm{VBM}^{16}$.

In general, there is still some controversy regarding the effects of nitrogen doping on $\mathrm{Cu}_{2} \mathrm{O}$, and no comprehensive understanding has yet been reached. It is well known that impurities at different sites in the lattice have distinct effects on the electrical and optical properties of a material, ${ }^{9,10}$. However, interstitial nitrogen $\left(\mathrm{N}_{\mathrm{i}}\right)$ in $\mathrm{Cu}_{2} \mathrm{O}$ has long been ignored in previous experimental and theoretical studies, which have focused only on nitrogen impurities substituted at oxygen sites $\left(\mathrm{N}_{\mathrm{O}}\right)^{6,7,12,13,15-19}$. In this work, we found that even in the lightly doped samples, a considerable number of $\mathrm{N}_{\mathrm{i}}$ formed in $\mathrm{Cu}_{2} \mathrm{O}$, along with $\mathrm{N}_{\mathrm{O}}$ and oxygen vacancies $\left(\mathrm{V}_{\mathrm{O}}\right)$. In the course of annealing, migrating $\mathrm{N}_{\mathrm{i}}$ reacted with $\mathrm{V}_{\mathrm{O}}$ forming more $\mathrm{N}_{\mathrm{O}}$, thereby altering the corresponding contents of these point defects and resulting in a significant change of the optical and electrical properties of the material.

\section{Results}

$\mathrm{Cu}_{2} \mathrm{O}$ and $\mathrm{Cu}_{2} \mathrm{O}: \mathrm{N}$ films were obtained via the post-oxidation of $\mathrm{Cu}$ (111) films that were initially deposited on cplane $\mathrm{Al}_{2} \mathrm{O}_{3}$ buffered with a $400 \mathrm{~nm}$ thick, semi-insulating $\mathrm{ZnO}$ film ${ }^{20}$. Nitrogen doping was achieved by 
introducing a nitrogen plasma through a radio-frequency (RF) plasma gun during the oxidation process. It was found that a micro-zone phase separation occurs when fabricating $\mathrm{Cu}_{2} \mathrm{O}$ films at high temperatures, while oxidizing at $300^{\circ} \mathrm{C}$ resulted in single oriented $\mathrm{Cu}_{2} \mathrm{O}$ (111) films. So that this recipe was adopted for all samples used in this study. Figure 1(a) presents typical XRD $\theta-2 \theta$ scans for the samples. Only one peak corresponding to the $\mathrm{Cu}_{2} \mathrm{O}$ (111) plane can be observed, in addition to the $\mathrm{ZnO}(0002)$ and $\mathrm{Al}_{2} \mathrm{O}_{3}$ (0006) signals; these results are consistent with the in situ reflection high-energy electron diffraction (RHEED) observations, as shown in Figure 1(b). Thus no traces of $\mathrm{CuO}, \mathrm{Cu}$ or $\mathrm{Cu}_{3} \mathrm{~N}$ phases were found, suggesting high quality $\mathrm{Cu}_{2} \mathrm{O}$ with diluted nitrogen in the doped samples. The clear RHEED patterns also indicate the fine crystallinity of the films. Atomic force microscopy images (not shown) revealed a uniform surface with a root-mean-square roughness of $\sim 10 \mathrm{~nm}$ in a scan area of $10 \mu \mathrm{m} \times 10 \mu \mathrm{m}$.

The resistivities of the as-grown $\mathrm{Cu}_{2} \mathrm{O}$ and $\mathrm{Cu}_{2} \mathrm{O}: \mathrm{N}$ samples were approximately $340 \Omega \mathrm{cm}$ and $100 \Omega \mathrm{cm}$, respectively, measured by Hall effect. The carrier density and mobility of the $\mathrm{Cu}_{2} \mathrm{O}$ were 3.5 $\times 10^{14} \mathrm{~cm}^{-3}$ and $53 \mathrm{~cm}^{2} \mathrm{~V}^{-1} \mathrm{~s}^{-1}$, respectively. Interestingly, the $\mathrm{Cu}_{2} \mathrm{O}: \mathrm{N}$ sample demonstrated ambiguous p-type conduction behavior (Fig. S1 in the supplementary information), suggesting a low value for the Hall coefficient and/or the existence of hole traps. Annealing were applied to activate nitrogen related acceptors and/ or remove the hole traps ${ }^{17,19}$.

Figure 2(a) shows room temperature values for the hole density, mobility and resistivity of the $\mathrm{Cu}_{2} \mathrm{O}$ and $\mathrm{Cu}_{2} \mathrm{O}: \mathrm{N}$ samples after annealing at $750^{\circ} \mathrm{C}$ for $10 \mathrm{~min}$ as functions of the nitrogen plasma power. A power of $0 \mathrm{~W}$ represents undoped $\mathrm{Cu}_{2} \mathrm{O}$. It is clear that the hole density increased with the power of the nitrogen plasma (likely to be proportional to the doping level) and the mobilities of $\mathrm{Cu}_{2} \mathrm{O}: \mathrm{N}$ were all smaller than those of $\mathrm{Cu}_{2} \mathrm{O}$ (also consistent with the hypothesis of high nitrogen incorporation). The hole concentrations of $\mathrm{Cu}_{2} \mathrm{O}: \mathrm{N}$ were in the range of $10^{16} \mathrm{~cm}^{-3}$, i.e. two orders of magnitude higher than that of $\mathrm{Cu}_{2} \mathrm{O}^{12,17-19}$. Figure 2(b) presents the room temperature $\mathrm{Hall}$ data for $\mathrm{Cu}_{2} \mathrm{O}: \mathrm{N}$ synthesized using nitrogen plasma power of $200 \mathrm{~W}$, as a function of annealing temperature. The lowest resistivity and the highest hole density were obtained upon annealing at $750^{\circ} \mathrm{C}$. When the sample was annealed at $800^{\circ} \mathrm{C}$, although the mobility was higher because of the improved crystal quality, the hole density decreased, leading to reduced conductivity. A possible explanation is that annealing at such a high temperature may also induce the out diffusion of nitrogen in addition to the acceptor activation. Note that the annealing conditions can be further optimized for better conductivity; nevertheless, in our study, the results indicated that the samples annealed at $750^{\circ} \mathrm{C}$ were already suitable for the study of nitrogen-related defects on behalf of the prominent evolution in electrical properties. Furthermore, the temperature- dependent hole concentration was also measured to determine the activation energy of the dominant acceptors in $\mathrm{Cu}_{2} \mathrm{O}: \mathrm{N}$, which was calculated to be $121 \mathrm{meV}$ (supplementary information). This level is attributed to extrinsic $\mathrm{N}_{\mathrm{O}}$ acceptors, because the only reasonable alternative of copper vacancies $\left(\mathrm{V}_{\mathrm{Cu}}\right)$ exhibits a much deeper level $^{21-23}$. Figure 3 presents the nitrogen concentration versus depth profiles of the $\mathrm{Cu}_{2} \mathrm{O}: \mathrm{N}$ films doped with $200 \mathrm{~W}$ nitrogen plasma as measured by secondary ion mass spectroscopy (SIMS), which confirms: (i) nitrogen incorporation into our films and (ii) its gradual out diffusion during anneals.

\section{Discussion}

The data in Fig. 2 and Fig. 3 suggest that nitrogen, likely in favor of $\mathrm{N}_{\mathrm{O}}$, behaves as an efficient acceptor in $\mathrm{Cu}_{2} \mathrm{O}: \mathrm{N}$. Logically, to enhance the conductivity of $\mathrm{Cu}_{2} \mathrm{O}: \mathrm{N}$, we simply need to increase the doping level and/or optimize the annealing process to balance the activation and outward-diffusion processes. However, the microscopic picture of the doping mechanism is still not clarified. $\mathrm{N}_{\mathrm{O}}$ is likely not the only defect type introduced by nitrogen doping. As is well known, when aliovalent substitutions occur in ionic compounds, a charge-compensation mechanism is required to ensure that the overall charge remains neutral. For $\mathrm{Cu}_{2} \mathrm{O}: \mathrm{N}$ with ionized $\mathrm{N}_{\mathrm{O}}$ acceptors, the compensation can be achieved, e.g. through the formation of anion vacancies $\left(\mathrm{V}_{\mathrm{O}}\right)$ or less likely, cation interstitials $\left(\mathrm{Cu}_{\mathrm{i}}\right)$ though their formation energy is relatively high ${ }^{21,22}$.

Photoluminescence (PL) is a non-destructive technique for the investigation of defects in semiconductors. The PL spectrum of $\mathrm{Cu}_{2} \mathrm{O}$ has been adequately researched in the literature, and the luminescence related to excitons, $\mathrm{V}_{\mathrm{O}}$, and $\mathrm{V}_{\mathrm{Cu}}$ has been well established ${ }^{24-26}$. However, previous research has not produced sufficient results with respect to PL studies of $\mathrm{Cu}_{2} \mathrm{O}: \mathrm{N}$. Ishizuka et al. have reported that $\mathrm{Cu}_{2} \mathrm{O}: \mathrm{N}$ exhibits no PL peak prior to hydrogen or crown-ether cyanide treatment, indicating the existence of non-radiative recombination centers in the polycrystalline $\mathrm{Cu}_{2} \mathrm{O}^{18,19}$.

Figure 4(a) presents the PL spectra of the $\mathrm{Cu}_{2} \mathrm{O}$ samples, with arrows indicating positions related to the excitons, $\mathrm{V}_{\mathrm{O}}$ and $\mathrm{V}_{\mathrm{Cu}}$. The presence of $\mathrm{V}_{\mathrm{O}}$ is due to the oxygen-lean growth conditions. After high-temperature annealing, the exciton luminescence was remarkably enhanced, whereas the intensity of the $\mathrm{V}_{\mathrm{O}}$ signature did not change significantly, suggesting an improvement in crystal quality after annealing. Notably, the formation of $\mathrm{V}_{\mathrm{Cu}}$ was suppressed because of the oxygen-lean conditions during growth, enabling a strong exciton luminescence ${ }^{25,26}$. The shape of the exciton luminescence peak can be well interpreted in terms of phononassisted transitions, as discussed in Ref. 26.

Figure 4(b) presents the spectra of the $\mathrm{Cu}_{2} \mathrm{O}: \mathrm{N}$ films while the spectrum of the $\mathrm{Cu}_{2} \mathrm{O}$ sample annealed at $750^{\circ} \mathrm{C}$ is also included as a reference. The most distinguishable features are the suppressed
( a )

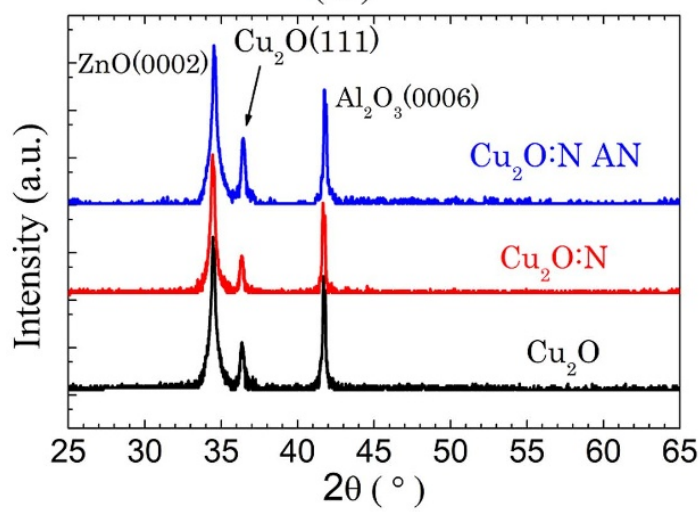

( b )

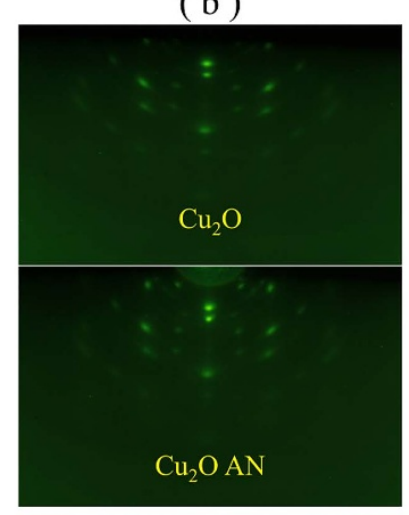

Figure $1 \mid$ (a) Typical XRD $\theta-2 \theta$ scans of the samples and (b) in situ RHEED patterns of undoped $\mathrm{Cu}_{2} \mathrm{O}$ sample, which are similar to those of $\mathrm{Cu}_{2} \mathrm{O}$ : $\mathrm{N}$. 
(a)

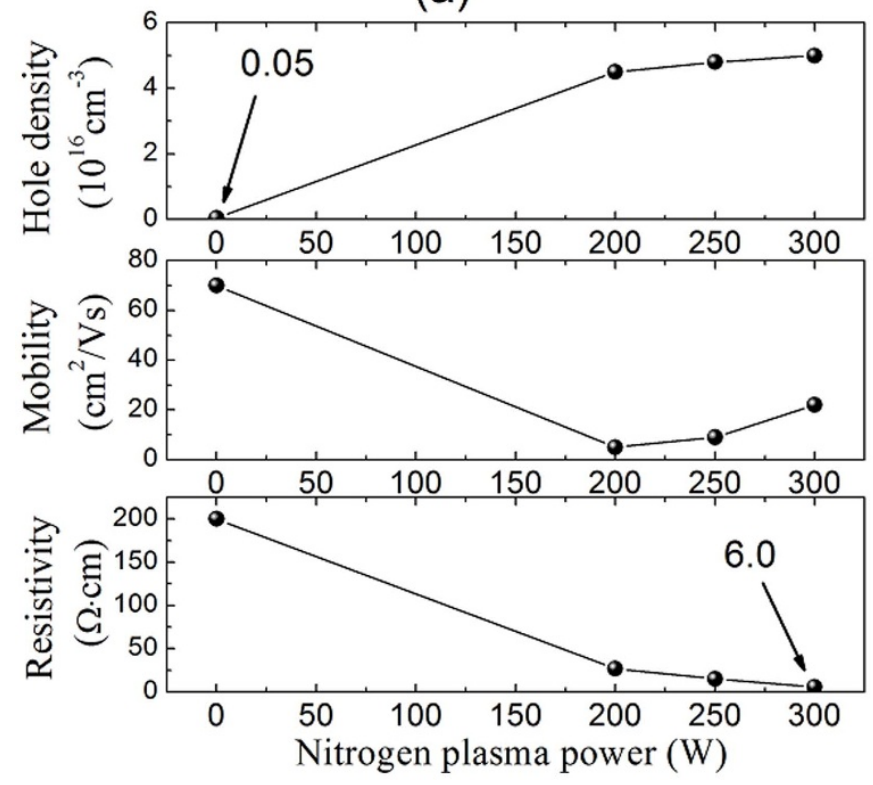

(b)

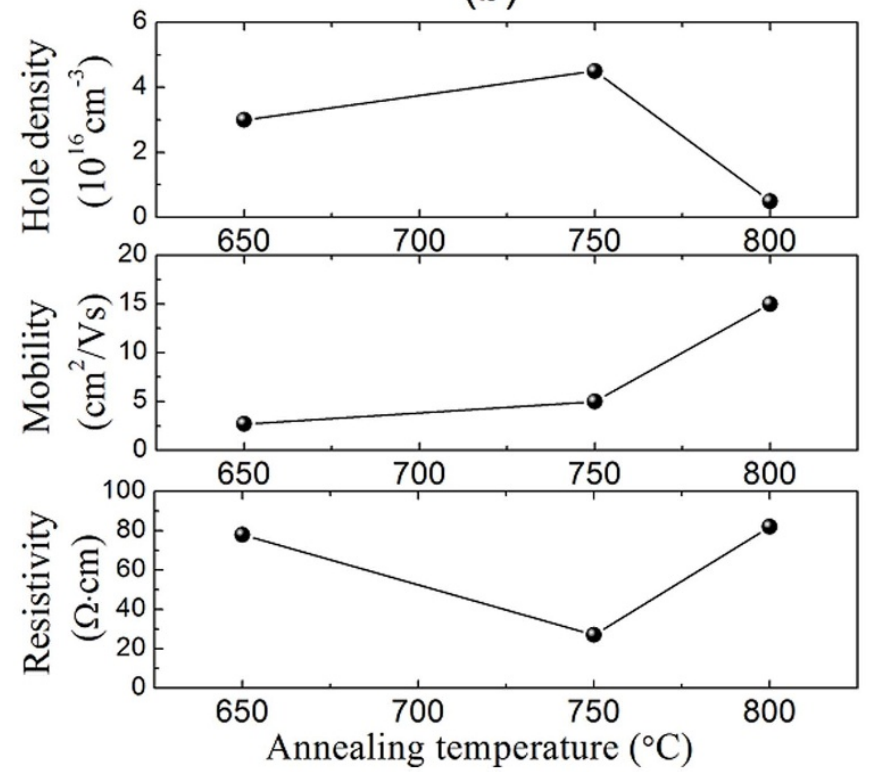

Figure $2 \mid$ Hole density, hole mobility, and resistivity of (a) $\mathrm{Cu}_{2} \mathrm{O}: \mathrm{N}$ samples annealed at $750^{\circ} \mathrm{C}$ as functions of the nitrogen plasma power (a power of $0 \mathrm{~W}$ represents an undoped sample) and (b) $\mathrm{Cu}_{2} \mathrm{O}: \mathrm{N}$ samples doped with a nitrogen plasma power of $200 \mathrm{~W}$ as functions of the annealing temperature.

exciton luminescence and intense $\mathrm{V}_{\mathrm{O}}$-related luminescence of the $\mathrm{Cu}_{2} \mathrm{O}$ : $\mathrm{N}$ films after annealing, supporting our hypothesis that incorporation of nitrogen is associated with the $\mathrm{V}_{\mathrm{O}}$ generation. Concurrently it has been demonstrated that the presence of $V_{O}$ has no responsibility for damping the exciton luminescence ${ }^{25,26}$, suggesting other traps to be involved and specifically $\mathrm{N}_{\mathrm{i}}$ and $\mathrm{N}_{\mathrm{O}}$ may be considered as prime candidates for non-radiative recombination mechanisms.

Indeed, the exciton luminescence was slightly enhanced (see Fig. 4(c)), whereas the intensity of the $\mathrm{V}_{\mathrm{O}}$ signal, in contrast, decreased with increasing annealing temperature. Taking into account the fact that PL intensities are proportional to defect contents, the evolution of the $\mathrm{V}_{\mathrm{O}}$ signature suggests that the annealing processes somehow reduced the $\mathrm{V}_{\mathrm{O}}$ content in the $\mathrm{Cu}_{2} \mathrm{O}: \mathrm{N}$ samples. It should be mentioned that the as-grown $\mathrm{Cu}_{2} \mathrm{O}: \mathrm{N}$ sample is likely to contain the highest density of $\mathrm{V}_{\mathrm{O}}$; however, this fact was not directly reflected by the PL intensity because of the poorer crystallinity of the as-grown sample. Considering that the annealing process played a limited role in repairing the $\mathrm{V}_{\mathrm{O}}$ in the undoped $\mathrm{Cu}_{2} \mathrm{O}$ (see Fig. 4(a) and Ref. 26), this trend of decreased $\mathrm{V}_{\mathrm{O}}$ concentration in $\mathrm{Cu}_{2} \mathrm{O}: \mathrm{N}$

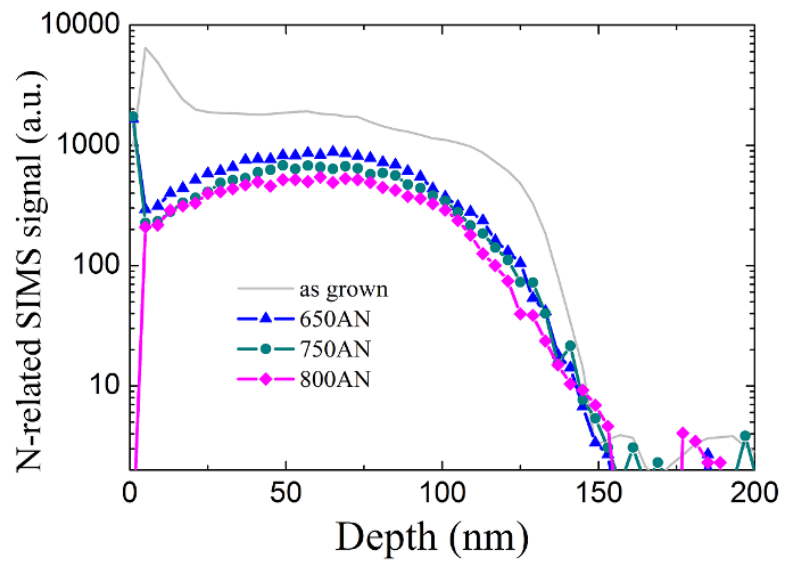

Figure $3 \mid$ Nitrogen concentration versus depth profiles in $\mathrm{Cu}_{2} \mathrm{O}: \mathrm{N}$ samples. should be attributed to the evolution of defects not available in the undoped films. A reasonable explanation is the refilling of $\mathrm{V}_{\mathrm{O}}$ by interstitial atoms, likely $\mathrm{N}_{\mathrm{i}}$, which move faster at higher temperatures and thus can more easily occupy the vacancy sites. Interstitial oxygen $\left(\mathrm{O}_{\mathrm{i}}\right)$ is another possible candidate to react with $\mathrm{V}_{\mathrm{O}}$; however, its formation is disfavored under oxygen-lean growth conditions ${ }^{21,22}$. Thus, the difficulty encountered in judging the conduction type of the as-grown $\mathrm{Cu}_{2} \mathrm{O}: \mathrm{N}$ based on the Hall measurements is the natural result of the presence of less $\mathrm{N}_{\mathrm{O}}$ and more $\mathrm{N}_{\mathrm{i}}$ in the film.

Further evidence for $\mathrm{N}_{\mathrm{i}}$ is observed in Figure 4(c), the enlarged spectra of the $\mathrm{Cu}_{2} \mathrm{O}: \mathrm{N}$ films in the vicinity of the exciton level. The asgrown $\mathrm{Cu}_{2} \mathrm{O}: \mathrm{N}$ sample exhibited a unique signature located at $\sim 652 \mathrm{~nm}(1.90 \mathrm{eV})$. This signal did not originate from the $\beta$ band in nonstoichiometric $\mathrm{Cu}_{2} \mathrm{O}$, despite the very similar energy level $(1.91 \mathrm{eV})$ because the $\beta$ band created by exciton-defect complexes would not be affected by the annealing process ${ }^{27,28}$. It cannot be related to $\mathrm{N}_{\mathrm{O}}$; if it were, it would not have disappeared after annealing. Therefore, this $652 \mathrm{~nm}$ peak is most likely attributable to the emission related to $\mathrm{N}_{\mathrm{i}}$. The absence of this signature in the annealed samples is the result of the diffusion of nitrogen out of the material and the transformation of $\mathrm{N}_{\mathrm{i}}$ into $\mathrm{N}_{\mathrm{O}}$. This interpretation is reasonable, considering the variation in the $\mathrm{V}_{\mathrm{O}}$ signature and the electrical properties.

It is worth noting that for all our samples, no signature could be observed at approximately $680 \mathrm{~nm}$ (Fig. 4(b)), where Ishizuka et al. observed a lone peak in the PL spectrum of $\mathrm{Cu}_{2} \mathrm{O}: \mathrm{N}$ after passivation treatment ${ }^{18,19}$. Park et al. have also reported the observation of this $680 \mathrm{~nm}$ luminescence signature in $\mathrm{Cu}_{2} \mathrm{O}$ films without intentional doping $^{29}$, indicating that the origin of this feature in polycrystalline $\mathrm{Cu}_{2} \mathrm{O}$ thin films remains uncertain.

In order to extend our interpretation, we applied X-ray photoelectron spectroscopy/X-ray Auger electron spectroscopy (XPS/XAES) to probe the defects ${ }^{30-32}$. A comparative study was conducted using four samples - two as-grown and two $750^{\circ} \mathrm{C}$ annealed samples of $\mathrm{Cu}_{2} \mathrm{O}$ and $\mathrm{Cu}_{2} \mathrm{O}: \mathrm{N}$, labeled as $\mathrm{Cu}_{2} \mathrm{O}, \mathrm{Cu}_{2} \mathrm{O} A N, \mathrm{Cu}_{2} \mathrm{O}: \mathrm{N}$, and $\mathrm{Cu}_{2} \mathrm{O}: \mathrm{N}$ AN, respectively. Notably, the confirmation of the nitrogen atoms' locations from their chemical states or bonding status is impractical because no signal related to nitrogen could be detected because of the low doping level $\left(\sim 10^{18} \mathrm{~cm}^{-3}\right)$. Instead, we relied on 
(a)

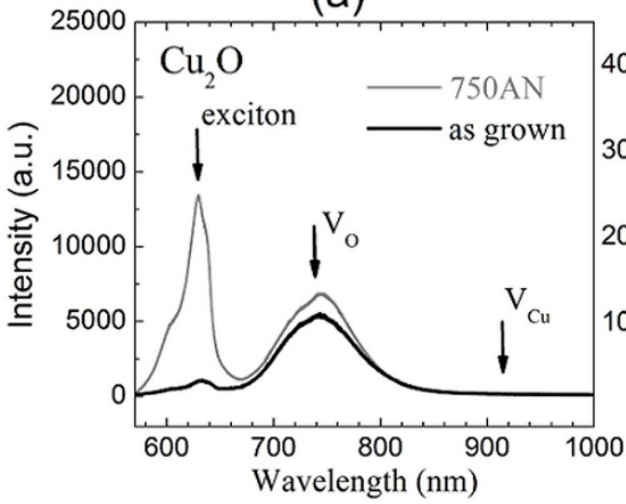

(b)

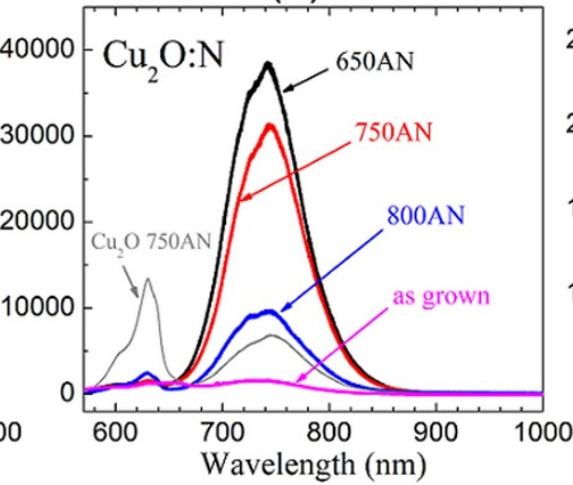

(c)

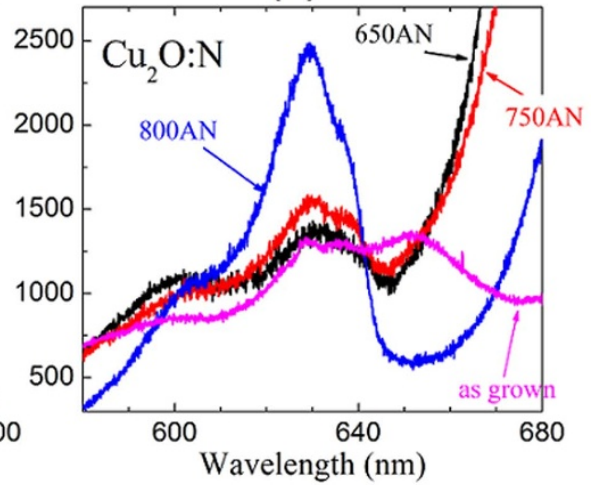

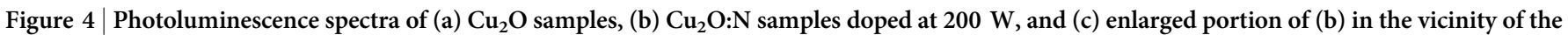
exciton emission.

the detection of other defects to interpret the formation and evolution of nitrogen-related defects by means of the defects' interactions.

Figure 5 presents the high-resolution XPS spectra of the (a) Cu2p and (b) O1s core levels. As shown in Fig. 5(a), the Cu-related peaks exhibit a symmetric shape with no satellite structure at approximately $943 \mathrm{eV}$, ruling out the presence of $\mathrm{Cu}^{2+}$ in these films. The fitting of the $\mathrm{Cu} 2 \mathrm{p} 3 / 2$ peaks indicates a binding energy of $932.6 \mathrm{eV}$, corresponding to that of $\mathrm{Cu}^{+}$in $\mathrm{Cu}_{2} \mathrm{O}$. The presence of metallic $\mathrm{Cu}$ clusters may also be ruled out accounting for: (i) the $\mathrm{Cu} 2 \mathrm{p}$ peaks exhibit strong symmetry, and the full widths at half maximum (FWHM) for all different samples are nearly identical (1.43$1.49 \mathrm{eV}$ ); (ii) the XRD results show no evidence of $\mathrm{Cu}$ (Fig. 1); and (iii) the samples exhibited good p-type conductivity. Further, the signatures of the $\mathrm{O} 1$ s peaks at $530.4 \mathrm{eV}$ are consistent with $\mathrm{O}$-state in $\mathrm{Cu}_{2} \mathrm{O}$ too. Notably, a much more pronounced variation in the FWHM values (1.15-1.58 eV, see Fig. 5(b)) indicates a trend that may be correlated with the presence of $\mathrm{V}_{\mathrm{O}}$ based on literature interpretations of oxygen deficient samples ${ }^{30,31}$.

As XAES is much more sensitive to the nature of the neighboring bonds and/or point defects than XPS ${ }^{30,32}$, the evolution of Cu LMM Auger lines was measured and Fig. 6 shows typical Cu-related signatures deconvoluted with five different components. Notably, three peaks located at $913.5 \mathrm{eV}, 919.5 \mathrm{eV}$ and $921.4 \mathrm{eV}$ are known not to be sensitive to the chemical environment ${ }^{33-35}$. The dominating peaks in Fig. 6 at $916.8 \mathrm{eV}$ (labeled as peak 1) and $918.3 \mathrm{eV}$ (labeled as peak 2) are typically attribute to $\mathrm{Cu}_{2} \mathrm{O}$ and $\mathrm{Cu}$, respectively, though peak 2 can also be observed in nonstoichiometric $\mathrm{Cu}_{2} \mathrm{O}^{33,34}$. In fact, the appearance of peak 2 in Fig. 6 is intriguing since we have ruled out the presence of $\mathrm{Cu}_{\mathrm{i}}$ or $\mathrm{Cu}$ cluster in our films. An alternative identification of peak 2 may be to assign it to $\mathrm{V}_{\mathrm{O}}$, since strong localized unpaired electrons of copper atoms neighboring $\mathrm{V}_{\mathrm{O}}$ might influence its effective charge state readily detectable by XAES ${ }^{21,22,30}$. In another words, the signal of $\mathrm{Cu}$ next to $\mathrm{V}_{\mathrm{O}}\left(-\mathrm{O}-\mathrm{Cu}-\mathrm{V}_{\mathrm{O}^{-}}\right)$, i.e. $\mathrm{Cu}$ dangling bond, is distinguishable from $\mathrm{Cu}^{1+}(-\mathrm{O}-\mathrm{Cu}-\mathrm{O}-)$, assuming that one $\mathrm{V}_{\mathrm{O}}$ would lead to an "aggregation" of four $\mathrm{Cu}$ atoms (Fig. S3 in the supplementary information).

Adopting this identification, further conclusions may be done considering the evolution of the peaks intensities in Fig. 6 . Notably, the annealing results in much more pronounced decrease of the $\mathrm{V}_{\mathrm{O}}$ content (in terms of the integrated intensity ratio of peak1 and peak 2) in $\mathrm{Cu}_{2} \mathrm{O}: \mathrm{N}$, comparing to that in $\mathrm{Cu}_{2} \mathrm{O}$, which is consistent with the PL results, altogether suggesting a critical role of $\mathrm{N}_{\mathrm{i}}$ to interact with $\mathrm{V}_{\mathrm{O}}$ in the course of annealing. Indeed, during annealing, the supply of atmospheric oxygen is insufficient to change $\mathrm{V}_{\mathrm{O}}$ concentration drastically, while the presence of $\mathrm{N}_{\mathrm{i}}$ in $\mathrm{Cu}_{2} \mathrm{O}: \mathrm{N}$ makes the major contribution to interact with $\mathrm{V}_{\mathrm{O}}$ forming $\mathrm{N}_{\mathrm{O}}$.

The higher ratio of the annealed $\mathrm{Cu}_{2} \mathrm{O}: \mathrm{N}$ sample indicates the lower $\mathrm{V}_{\mathrm{O}}$ content, i.e., fewer $\mathrm{Cu}$ dangling bonds, compared with the annealed $\mathrm{Cu}_{2} \mathrm{O}$ sample; this finding reflects the important influence of the growth conditions, as the nitrogen plasma provided additional total anions. One may argue that this result seems to be in conflict with the stronger $\mathrm{V}_{\mathrm{O}}$-related luminescence of $\mathrm{Cu}_{2} \mathrm{O}: \mathrm{N}$, as shown in Figure 5(b). We attribute this phenomenon to the passivation effect of nitrogen ${ }^{36}$, which arises because $\mathrm{N}_{\mathrm{i}}$ can also move to defect sites other than $\mathrm{V}_{\mathrm{O}}$. This passivation effect is further evidence of significant $\mathrm{N}_{\mathrm{i}}$ formation induced by doping. Ishizuka et al. also observed an enhanced PL intensity after nitrogen doping ${ }^{18}$.

Notably, the fitted FWHMs of peak 1 for the $\mathrm{Cu}_{2} \mathrm{O}: \mathrm{N}$ samples (Table 1) are slightly broadened compared with those of the undoped $\mathrm{Cu}_{2} \mathrm{O}$ samples. Fixing the FWHMs of peak 1 yielded very similar (a)

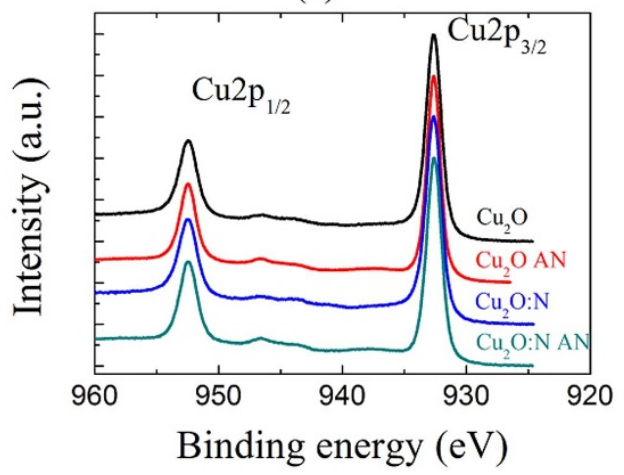

(b)

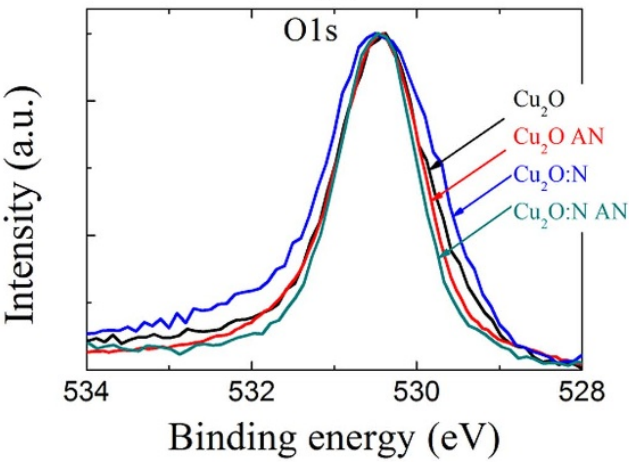

Figure $5 \mid$ XPS (a) Cu 2p spectra, and (b) normalized $\mathrm{O} 1 \mathrm{~s}$ spectra of $\mathrm{Cu}_{2} \mathrm{O}$ and $\mathrm{Cu}_{2} \mathrm{O}: \mathrm{N}$ samples. 

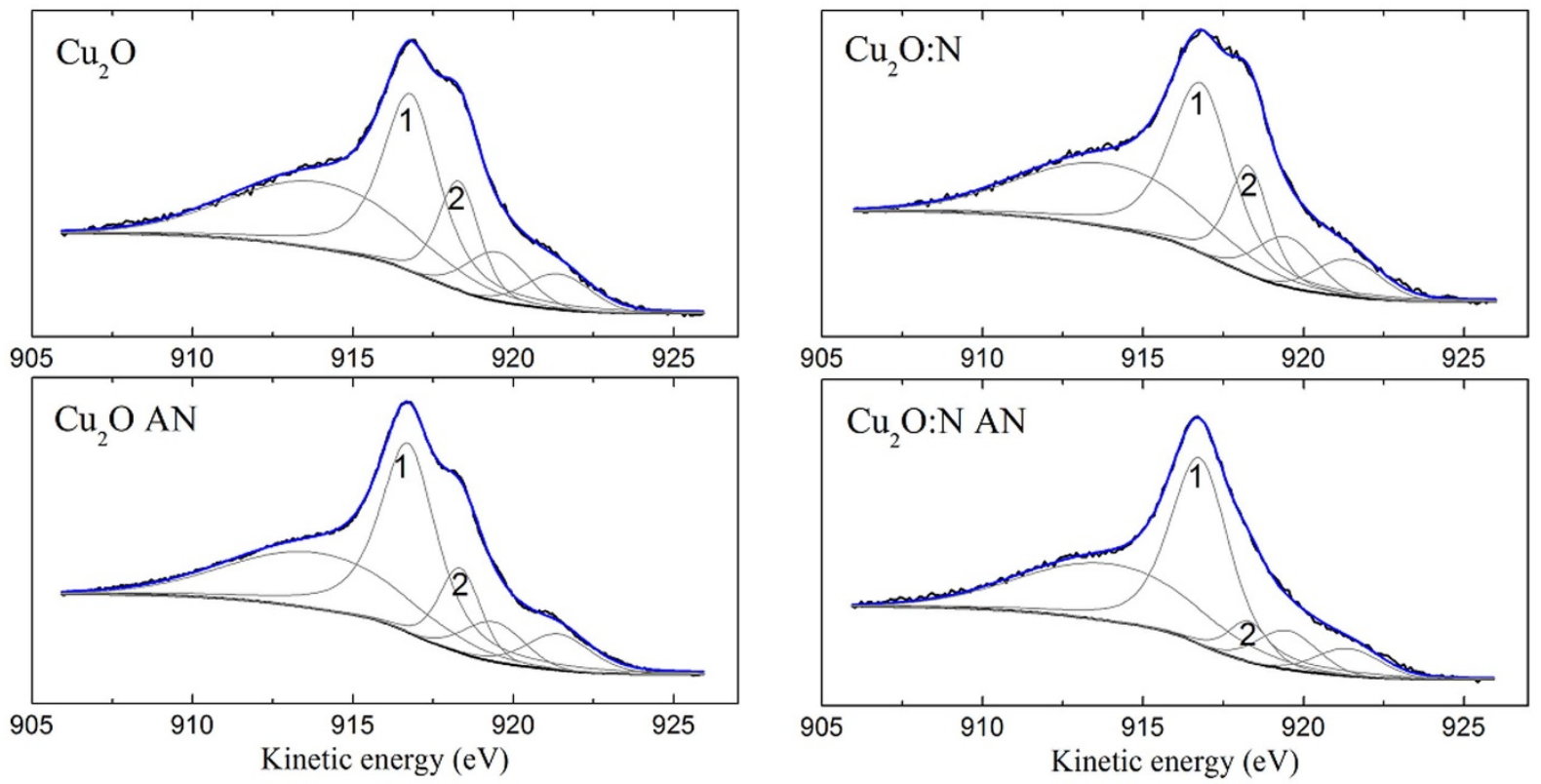

Figure 6 | $\mathrm{Cu}$ LMM spectra demonstrated with 5 different components for the $\mathrm{Cu}_{2} \mathrm{O}$ (left column) and $\mathrm{Cu}_{2} \mathrm{O}: \mathrm{N}$ (right column).

fitting results; however, it was found that allowing this broadening improved the fit considerably, yielding a smaller standard deviation. This broadening is interpreted as a sensitive indication of $\mathrm{Cu}-\mathrm{N}$

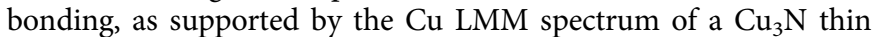
film, which exhibits a similar shape to that of $\mathrm{Cu}_{2} \mathrm{O}$, also with a predominant peak at $916.8 \mathrm{eV}$ (supplementary information).

In conclusion, $\mathrm{Cu}_{2} \mathrm{O}$ and $\mathrm{Cu}_{2} \mathrm{O}: \mathrm{N}$ thin films were synthesized through the oxidation of $\mathrm{Cu}$ films. $\mathrm{N}_{\mathrm{O}}$ acceptors effectively enhance the conductivity of such films, with an activation energy of approximately $121 \mathrm{meV}$. Probing the defects in the films using a combination of PL and XPS/XAES revealed the formation of $\mathrm{N}_{\mathrm{i}}$ and the enhancement of the $\mathrm{V}_{\mathrm{O}}$ content in the prepared $\mathrm{Cu}_{2} \mathrm{O}: \mathrm{N}$ thin films. The evolution of the optical and electrical properties of these films can be consistently explained in terms of the $\mathrm{N}_{i}$ interacting with $\mathrm{V}_{\mathrm{O}}$ and the resultant transformation into $\mathrm{N}_{\mathrm{O}}$ in the course of annealing.

\section{Methods}

The samples were fabricated in an ultra-high-vacuum chamber with a background pressure within the lower range of $10^{-7} \mathrm{~Pa}$. A conventional Knudsen cell was used to evaporate metallic $\mathrm{Cu}(6 \mathrm{~N})$. $\mathrm{Cu}(111)$ films were initially deposited on c-plane $\mathrm{Al}_{2} \mathrm{O}_{3}$ buffered with a $400 \mathrm{~nm}$ thick semi-insulating $\mathrm{ZnO}(0001)$ film. $\mathrm{Cu}_{2} \mathrm{O}$ films were obtained via post-oxidation using oxygen plasma, and $\mathrm{Cu}_{2} \mathrm{O}: \mathrm{N}$ films were obtained under similar conditions through co-treatment with oxygen and nitrogen plasmas. Specifically, the oxygen plasma was used at a fixed $\mathrm{O}_{2}$ flux of $1 \mathrm{sccm}$ (the partial pressure was maintained within the lower range of $10^{-3} \mathrm{~Pa}$ ), and discharged via RF power. The doping level was controlled by varying the RF power and the $\mathrm{N}_{2}$ flux. The thickness of the prepared films was approximately $150 \mathrm{~nm}$. The oxidation/doping temperature was $300^{\circ} \mathrm{C}$ for all samples. The typical oxidation time was approximately 90 minutes. The oxidation process was monitored by means of in situ reflection highenergy electron diffraction (RHEED) observations. Once the RHEED pattern indicated complete oxidation of $\mathrm{Cu}$ into $\mathrm{Cu}_{2} \mathrm{O}$, the plasma exposure was terminated.

\begin{tabular}{|lrrrrrc|}
\hline \multicolumn{6}{l}{ Table 1 | Summary of the Cu LMM peak-fitting parameters } \\
Sample & Peak & K.E. [eV] & Intensity & FWHM [eV] & Intensity ratio \\
\hline $\mathbf{C u}_{\mathbf{2}} \mathbf{O}$ & 1 & 916.8 & 19252.42 & 2.10 & 2.56 \\
& 2 & 918.3 & 7519.22 & 1.52 & \\
$\mathbf{C u}_{\mathbf{2}} \mathbf{O} \mathbf{A N}$ & 1 & 916.7 & 22386.87 & 2.10 & 3.61 \\
$\mathbf{C u}_{\mathbf{2}} \mathbf{O}: \mathbf{N}$ & 2 & 918.3 & 6193.66 & 1.52 & \\
$\mathbf{C u}_{\mathbf{2}} \mathbf{O}: \mathbf{N}$ AN & 1 & 916.8 & 12843.29 & 2.30 & 2.43 \\
& 2 & 918.3 & 5276.19 & 1.52 & \\
& 2 & 916.8 & 18128.31 & 2.20 & 6.83 \\
\hline
\end{tabular}

Shorter or longer treatment times would result in undesired phases of $\mathrm{Cu}$ and $\mathrm{CuO}$, respectively. More details can be found in our previous report ${ }^{20}$.

Several samples were subjected to post-annealing in the same chamber under an oxygen-gas atmosphere (also at $\sim 10^{-3} \mathrm{~Pa}$ ) at various temperatures. The temperature ramping rate was $30^{\circ} \mathrm{C} \mathrm{min}^{-1}$. Once the set temperature was reached, that temperature was maintained for $10 \mathrm{~min}$, and the sample was then cooled at the same rate of $30^{\circ} \mathrm{C} \mathrm{min}^{-1}$.

XRD measurements were performed using a Mac Science M18XHF diffractometer with a $\mathrm{Cu} \mathrm{K} \alpha$ radiation source $(\lambda=1.5406 \AA)$ at $40 \mathrm{kV}$ and $50 \mathrm{~mA}(2 \mathrm{~kW})$.

The van der Pauw configuration was used for the Hall measurements. Roomtemperature tests were performed using an Ecopia HMS-3000 system, and the results were double-checked using a home-made Hall system. The Hall coefficient was extracted from the trace curve of the transverse voltage recorded using an alternating magnetic field and a constant current (supplementary information). The temperature-dependent hole density was recorded using a Lakeshore model 7604 Hall system. The acceptor level was extracted using the following equation:

$$
p=\frac{N_{A}-N_{D}}{2 N_{D}} N_{v} \exp \left(\frac{-E_{A}}{k T}\right)
$$

where $N_{A}, N_{D}, N_{v}, E_{A}, k$ and $T$ are the acceptor density, donor density, effective density of states in the valence band, acceptor level, Boltzmann constant, and absolute temperature, respectively, and

$$
N_{v}=2\left(2 \pi m_{h} k T / h\right)^{3 / 2}
$$

where $m_{h}$ and $h$ are the hole effective mass and the Plank constant, respectively.

For the photoluminescence measurements, the samples were excited using a $532 \mathrm{~nm}$ laser at $1 \mathrm{~mW}$ focused to a spot of approximately $2 \mu \mathrm{m}$. The spectra were measured at room temperature in a back-scattering geometry. The integration time was 10 seconds in all cases.

SIMS measurements were performed using a Cameca IMS $7 \mathrm{f}$ microanalyzer.

XPS measurements were performed using a PHI-5300 ESCA Spectrometer with a monochromatic $\mathrm{Al} \mathrm{k}_{\alpha} \mathrm{X}$-ray source at $1486.6 \mathrm{eV}$. All data were collected at a nominal depth of $6 \mathrm{~nm}$ after Ar-ion sputtering, and the damage effect proved to be negligible (supplementary information). Spectral analysis was performed using XPSPeak version 4.1. Shirley background subtraction was adopted, and the fitting results were determined based on the minimum standard deviation.

1. Hara, M. et al. $\mathrm{Cu}_{2} \mathrm{O}$ as a photocatalyst for overall water splitting under visible light irradiation. Chem. Commun. 3, 357-358 (1998).

2. Hu, C.-C., Nian, J.-N. \& Teng, H. Electrodeposited p-type $\mathrm{Cu}_{2} \mathrm{O}$ as photocatalyst for $\mathrm{H}_{2}$ evolution from water reduction in the presence of $\mathrm{WO}_{3}$. Sol. Energy Mater. Sol. Cells 92, 1071-1076 (2008).

3. Kuo, C.-H., Yang, Y.-C., Gwo, S. \& Huang, M. H. Facet-Dependent and Au

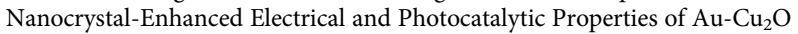
Core-Shell Heterostructures. J. Am. Chem. Soc. 133, 1052-1057 (2011).

4. Huang, W.-C., Lyu, L.-M., Yang, Y.-C. \& Huang, M. H. Synthesis of $\mathrm{Cu}_{2} \mathrm{O}$ Nanocrystals from Cubic to Rhombic Dodecahedral Structures and Their Comparative Photocatalytic Activity. J. Am. Chem. Soc. 134, 1261-1267 (2012). 
5. Kalidindi, S. B., Sanyal, U. \& Jagirdar, B. R. Nanostructured $\mathrm{Cu}$ and $\mathrm{Cu} @ \mathrm{Cu}_{2} \mathrm{O}$ core shell catalysts for hydrogen generation from ammonia-borane. Phys. Chem. Chem. Phys. 10, 5870-5874 (2008).

6. Malerba, C. et al. Nitrogen doped $\mathrm{Cu}_{2} \mathrm{O}$ : A possible material for intermediate band solar cells? Sol. Energy Mater. Sol. Cells 105, 192-195 (2012).

7. Lee, Y. S. et al. Nitrogen-doped cuprous oxide as a p-type hole-transporting layer in thin-film solar cells. Mater. Chem. A 1, 15416-15422 (2013).

8. Luque, A. \& Martí, A. Increasing the Efficiency of Ideal Solar Cells by Photon Induced Transitions at Intermediate Levels. Phys. Rev. Lett. 78, 5014-5017 (1997).

9. Diwald, O. et al. Photochemical Activity of Nitrogen-Doped Rutile $\mathrm{TiO}_{2}(110)$ in Visible Light. J. Phys. Chem. B 108, 6004-6008 (2004).

10. Valentin, C. D., Pacchioni, G., Selloni, A., Livraghi, S. \& Giamello, E. Characterization of Paramagnetic Species in N-Doped TiO2 Powders by EPR Spectroscopy and DFT Calculations. J. Phys. Chem. B 109, 11414-11419 (2005).

11. Kudo, A. \& Miseki, Y. Heterogeneous photocatalyst materials for water splitting. Chem. Soc. Rev. 38, 253-278 (2009).

12. Lai, G., Wu, Y., Lin, L., Qu, Y. \& Lai, F. Low resistivity of $\mathrm{N}$-doped $\mathrm{Cu}_{2} \mathrm{O}$ thin films deposited by rf-magnetron sputtering. Appl. Surf. Sci. 285B, 755-758 (2013).

13. Zang, Z., Nakamura, A. \& Temmyo, J. Nitrogen doping in cuprous oxide films synthesized by radical oxidation at low temperature. J. Mater. Lett. 92, 188-191 (2013).

14. Nakano, Y., Saeki, S. \& Morikawa, T. Optical bandgap widening of p-type $\mathrm{Cu}_{2} \mathrm{O}$ films by nitrogen doping. Appl. Phys. Lett. 94, 022111 (2009).

15. Li, M., Zhang, J.-Y., Zhang, Y. \& Wang, T.-M. Oxygen vacancy in $\mathrm{N}$-doped $\mathrm{Cu}_{2} \mathrm{O}$ crystals: A density functional theory study. Chin. Phys. B 21, 087301 (2012).

16. Zhao. et al. First-principles study on the doping effects of nitrogen on the electronic structure and optical properties of $\mathrm{Cu}_{2} \mathrm{O}$. RSC Adv. 3, 84-90 (2013).

17. Ishizuka, S., Kato, S., Maruyama, T. \& Akimoto, K. Nitrogen Doping into $\mathrm{Cu}_{2} \mathrm{O}$ Thin Films Deposited by Reactive Radio-Frequency Magnetron Sputtering. Jpn. J. Appl. Phys. 40, 2765-2768 (2001).

18. Ishizuka, S., Kato, S., Okamoto, Y. \& Akimoto, K. Hydrogen treatment for polycrystalline nitrogen-doped $\mathrm{Cu}_{2} \mathrm{O}$ thin film. J. Cryst. Growth 237-239, 616-620 (2002).

19. Okamoto, Y. et al. Passivation of defects in nitrogen-doped polycrystalline $\mathrm{Cu}_{2} \mathrm{O}$ thin films by crown-ether cyanide treatment. Appl. Phys. Lett. 82, 1060-1062 (2003).

20. Li, J. et al. Temperature dependence of $\mathrm{Cu}_{2} \mathrm{O}$ orientations in oxidation of $\mathrm{Cu}$ (111)/ZnO (0001) by oxygen plasma. Chin. Phys. B 21, 076401 (2012).

21. Raebiger, H., Lany, S. \& Zunger, A. Origins of the $p$-type nature and cation deficiency in $\mathrm{Cu}_{2} \mathrm{O}$ and related materials. Phys. Rev. B 76, 045209 (2007).

22. Soon, A., Cui, X.-Y., Delley, B., Wei, S.-H. \& Stampfl, C. Native defect-induced multifarious magnetism in nonstoichiometric cuprous oxide: First-principles study of bulk and surface properties of $\mathrm{Cu}_{2-\delta}$ O. Phys. Rev. B 79, 035205 (2009).

23. Paul, G. K., Nawa, Y., Sato, H., Sakurai, T. \& Akimoto, K. Defects in $\mathrm{Cu}_{2} \mathrm{O}$ studied by deep level transient spectroscopy. Appl. Phys. Lett. 88, 141901 (2006).

24. Itoh, T. \& Narita, S. Relaxed excitons in $\mathrm{Cu}_{2}$ O. J. Phys. Soc. Jpn. 39, 132-139 (1975).

25. Ito, T. \& Masumi, T. Detailed examination of relaxation processes of excitons in photoluminescence spectra of $\mathrm{Cu}_{2}$ O. J. Phys. Soc. Jpn. 66, 2185-2193 (1997)

26. $\mathrm{Li}$, J. et al. Engineering of optically defect free $\mathrm{Cu}_{2} \mathrm{O}$ enabling exciton luminescence at room temperature. Opt. Mater. Express 3, 2072-2077 (2013).

27. Zouaghi, M. Near infrared optical and photoelectric properties of $\mathrm{Cu}_{2} \mathrm{O}$ II. Near infrared Photoconductivity in $\mathrm{Cu}_{2} \mathrm{O}$ : Influence of annealing. phys. stat. sol. (a) 11, 219-227 (1972).

28. Zouaghi, M. Near infrared optical and photoelectric properties of $\mathrm{C}_{\mathrm{u} 2} \mathrm{O}$ III Interpretation of experimental results. phys. stat. sol. (a) 11, 449-460 (1972).
29. Park, J.-W. et al. Microstructure, optical property, and electronic band structure of cuprous oxide thin films. J. Appl. Phys. 110, 103503-103508 (2011)

30. Göpel, W. et al. Surface defects of $\mathrm{TiO}_{2}(110)$ : a combined XPS, XAES and ELS study. Surf. Sci. 139, 333-346 (1984).

31. Fan, J. C. C. \& Goodenough, J. B. X-ray photoemission spectroscopy studies of Sndoped indium-oxide films. J. Appl. Phys. 48, 3524-3531 (1977).

32. Schwidtal, K. SiO 2 Surface defect centers studied by AES. Surf. Sci. 77, 523-536 (1978).

33. Platzman, I., Brener, R., Haick, H. \& Tannenbaum, R. Oxidation of Polycrystalline Copper Thin Films at Ambient Conditions. J. Phys. Chem. C 112, 1101-1108 (2008).

34. Poulston, S., Parlett, P. M., Stone, P. \& Bowker, M. Surface Oxidation and Reduction of $\mathrm{CuO}$ and $\mathrm{Cu}_{2} \mathrm{O}$ Studied Using XPS and XAES. Surf. Interface Anal. 24, 811-820 (1996).

35. Antonides, E., Jose, E. C. \& Sewatzky, G. A. LMM Auger spectra of Cu, Zn, Ga, and Ge. I. Transition probabilities, term splittings, and effective Coulomb interaction. Phys. Rev. B 15, 1669-1679 (1977).

36. Chobpattana, V. et al. Nitrogen-passivated dielectric-InGaAs interfaces with sub$\mathrm{nm}$ equivalent oxide thickness and low interface trap densities. Appl. Phys. Lett. 102, 022907 (2013)

\section{Acknowledgments}

The authors would like to thank Prof. Rexi Kui and Prof. Jia-ou Wang for valuable discussions. This work was supported by the Ministry of Science and Technology of China (Grant Nos. 2011CB302002 and 2011CB302006), the National Science Foundation of China (Grant Nos. 11174348, 51272280, 11274366, 61204067, and 61306011), the Chinese Academy of Sciences, and the Research Council of Norway in the framework of the IDEAS grant program administered via the ENERGIX program.

\section{Author contributions}

Z.M., Q.M. and X.D. conceived and guided the study. J.L. and Z.M. designed the research and guided the work and analysis. J.L., H.L., L.L. and Y.L. conducted the growth and characterization of the $\mathrm{Cu}_{2} \mathrm{O}$. A.J. conducted the growth and characterization of the $\mathrm{Cu}_{3} \mathrm{~N}$ A.A. and A.K. performed the SIMS experiments. J.L. and A.K. wrote the paper. All authors discussed the results and commented on the manuscript.

\section{Additional information}

Supplementary information accompanies this paper at http://www.nature.com/ scientificreports

Competing financial interests: The authors declare no competing financial interests. How to cite this article: $\mathrm{Li}$, J. et al. Probing Defects in Nitrogen-Doped $\mathrm{Cu}_{2} \mathrm{O}$. Sci. Rep. 4, 7240; DOI:10.1038/srep07240 (2014).

This work is licensed under a Creative Commons Attribution-NonCommercialShareAlike 4.0 International License. The images or other third party material in this article are included in the article's Creative Commons license, unless indicated otherwise in the credit line; if the material is not included under the Creative Commons license, users will need to obtain permission from the license holder in order to reproduce the material. To view a copy of this license, visit http:// creativecommons.org/licenses/by-nc-sa/4.0/ 